TADEUSZ PALECZNY ${ }^{1}$

\title{
RECENZJA MONOGRAFII ZBIOROWEJ POD REDAKCJĄ MONIKI BANAŚ PT. KOBIETY W POLITYCE (KSIĘGARNIA AKADEMICKA, KRAKÓW 2018)
}

Po pierwszej pobieżnej lekturze tekstu recenzowanej monografii natychmiast, niemal automatycznie, zrodziło się we mnie kilka refleksji. Być może uwarunkowane są one kulturowo, może wynikają - używając kolokwializmu - z niepokoju etycznego związanego z udziałem i rolą kobiet w życiu publicznym, jaką wyznaczali im wcześniej mężczyźni. Być może z diagnozy istniejącego stanu rzeczy, polegającej na stwierdzeniu faktu, że chyba nikomu nie wpadłoby do głowy opracowanie tomu zatytułowanego Mężczyźni w polityce. Wydaje się bowiem oczywiste, że jest to sfera życia publicznego opanowana i zdominowana przez reprezentantów jednej płci. Natychmiast rodzi się jednak kolejna wątpliwość. Czy tak jest rzeczywiście? Czy sfera władzy jest z natury rzeczy zmaskulinizowana i kobiety odgrywają w niej drugorzędną rolę?

Od razu także rzuca się w oczy, że książka napisana jest wyłącznie przez kobiety. Zatem dla kogo? Dla samych siebie? A może jej cel jest bardziej dalekosiężny i przewrotny? Czy ma służyć w jakiejś, nawet bardzo małej mierze poprawie samopoczucia autorek, czy też prowadzić do opisu i wyjaśnienia miejsca i znaczenia kobiet w polityce? Jak rozumianej polityce? Czy ma to być studium historyczno-porównawcze czy też diagnoza istniejącego aktualnie stanu rzeczy?

Nie ukrywam, że już ten wstępny zestaw pytań i indeks problemów mocno mnie zaintrygował. Kwestia miejsca kobiet w życiu publicznym jest dyskutowana, najczęściej w pełnej emocji atmosferze, od co najmniej

\footnotetext{
${ }^{1}$ Prof. dr hab.; Uniwersytet Jagielloński w Krakowie; ORCID: 0000-0002-7272-8864; e-mail: tadeusz.paleczny@uj.edu.pl.
} 
stulecia. Faktem jest również, że debaty te inicjowały przeważnie same kobiety, domagając się dla siebie większej uwagi, udziału i znaczenia w sferze publicznej. Od razu zatem pojawia się pokusa, aby zaliczyć ten tom do nurtu feministycznej, czy raczej już postfeministycznej krytyki różnych, także późnych, nowożytnych wersji patriarchalizmu.

Już pierwsza lektura pozwoliła mi na odpowiedź na większość tych pytań. Zestaw autorek, reprezentujących różne dyscypliny nauk społecznych i humanistycznych, wskazuje na dobrze przemyślany projekt naukowy, polegający na poszukiwaniu przyczyn i następstw aktywności kobiet w polityce $\mathrm{w}$ różnych kręgach kulturowych, systemach społecznych i politycznych. Tom ma z całą pewnością charakter interdyscyplinarny oraz międzynarodowy, z tendencją do międzykulturowości. Zawiera pozornie odległe od siebie przejawy obecności kobiet w publicznej sferze aktywności, ich chęci i aspiracji do uczestnictwa w sprawowaniu władzy i do wpływania na własne losy. Teksty łączy jednak wspólna orientacja teoretyczna, polegająca na opartej na dobrym warsztacie naukowym krytycznej analizie kontekstu kulturowego i społecznego roli kobiet w polityce.

Publikację otwiera stosunkowo obszerny wstęp autorstwa redaktorki tomu, Moniki Banaś. Sposób podejścia do problematyki oparty został na przekonaniu o konieczności zapewnienia równorzędności i symetrii relacji płciowych i połączony z chęcią zrozumienia przyczyn ich braku. Sama Monika Banaś daje wyraz swojemu stanowisku, pisząc we wprowadzeniu:

Skromna obecność, a raczej wyrazista nieobecność kobiet w polityce ma wiele przyczyn, z których jedna wydaje się szczególnie istotna dla zrozumienia istoty problemu - uwarunkowania, a ściślej warunki uprawiania polityki: reguły, zwyczaje i obyczaje rządzące tą publiczną sferą. Nierzadko sprowadzające się do pozbawionej subtelności rywalizacji (czytaj: brutalnej walki), zniechęcają kobiety do aktywnego politycznego uczestnictwa. Programy edukacyjne, rekomendacje instytucji międzynarodowych i finansowanie projektów służących mobilizacji kobiet jako aktorek, a nie statystek sceny politycznej wydają się niewystarczające. Należy zatem zadać pytanie - dlaczego? Czy problemem jest zbyt mały zasięg owych programów, zbyt małe nagłośnienie problemu, czy może umocowane w sferze kulturowo-światopoglądowej przekonanie o tym, że głos kobiecy jest mniej ważny, mniej rozsądny, a więcej emocjonalny, czy mniej konkretny i merytoryczny? (s. 8)

Deklaracja intencji inicjatorki tomu została w dużym stopniu zrealizowana w tekstach dziesięciu autorek poszczególnych rozdziałów monografii. 
Pierwszy z nich, przygotowany przez Monikę Ślufińską, nosi tytuł Kobiety $i$ władza jako sfera zainteresowania polskich ośrodków eksperckich. Badaczka podnosi w nim problem politycznej roli i reprezentacji kobiet w działalności ośrodków mających wpływ na kształtowanie reguł i mechanizmów partycypacyjnych w polityce, także poprzez wywieranie nacisku na ośrodki władzy i mass media. Zdaniem autorki znacząco na funkcjonowanie sceny politycznej, zasad partycypacji i postrzegania roli kobiet w strukturach władzy wpływają ośrodki eksperckie, zwane think tankami. W wielu krajach, głównie o utrwalonych wzorach demokracji zachodniej, istnieją i funkcjonują liczne podmioty organizacyjne ułatwiające aktywizację kobiet w szeroko rozumianej polityce publicznej. Autorka przejrzyście ukazuje tło społeczne i polityczne, jak również kulturowy kontekst obecności problematyki kobiecej w działalności, w tym w procedurach finansowania i funkcjonowania think tanków w Stanach Zjednoczonych Ameryki, Republice Federalnej Niemiec, Wielkiej Brytanii i we Francji. Przechodząc na grunt polski, badaczka formułuje bardziej krytyczne opinie. Nieliczne organizacje ekspercko-doradcze w Polsce, takie jak Instytut Obywatelski czy Centrum im. Ignacego Daszyńskiego, próbują czynnie wpływać na wzrost obecności i aktywności polskich kobiet w życiu politycznym. Jest ich jednak zdaniem Ślufińskiej zbyt mało, są za mało widoczne i znaczące poza środowiskami o orientacji liberalno-lewicowej. Przyczyny niewielkiego znaczenia polskich, raczkujących dopiero think tanków na scenie politycznej wynikają według autorki z młodych stosunkowo struktur demokratycznej władzy, z niedojrzałości i braku doświadczeń elit politycznych, wyrastających na gruncie ubogiej, krótko kształtowanej kultury politycznej społeczeństwa obywatelskiego. Monika Ślufińska zwraca zarazem uwagę na podłoże ideologiczne różnicujące postawy wobec aktywności kobiet w polityce, które konstytuując centra kierownicze partii, wywierają wpływ na realną politykę wobec kwestii kobiecych, teorii gender, różnic płciowych i ich etycznych oraz religijnych uwarunkowań. Nie można nic zarzucić logiczności i przejrzystości tego rozdziału, strukturze wywodu, jak również sposobowi opisu oraz argumentacji, ukazującej asymetrię obecności kobiet w działalności think tanków.

Kolejna autorka, Magdalena Danek, prezentuje artykuł pt. Kobiety jako komentatorki życia publicznego w polskich programach publicystycznych. Jest to jeden z trzech tekstów, oprócz dwóch poprzednich, omawiający miejsce kobiet polskich $w$ polityce. Pozostałe dotyczą różnych aspektów i form uczestnictwa kobiet w politycznej sferze aktywności w innych krajach 
i kręgach kulturowych. Jest to warta podkreślenia międzynarodowa, wielokulturowa tematyka tomu, pozwalająca na nieuniknione, choć nieobecne $w$ tomie próby podejmowania studiów porównawczych. Autorka formułuje uzasadniony jej zdaniem stanem rzeczy sąd o niskiej statystycznie stopie obecności kobiet na eksponowanych stanowiskach politycznych. Niedobór i brak reprezentatywności rzeczywistej roli kobiet w przestrzeni publicznej pogłębiają według niej mass media, przyczyniające się do upowszechnienia przekonania o mniejszej ich roli i znaczeniu w strukturach władzy. Analizując polskie programy publicystyczne, Danek prezentuje ilościową charakterystykę programów emitowanych w czasie największej oglądalności. Wynik tych badań wskazuje na najwyżej 20-procentową reprezentację kobiet $w$ dyskusjach czy debatach medialnych w charakterze komentatorek i ekspertek bądź też reprezentantek władzy politycznej. Konkluzje autorki wydają się oczywiste. Poziom maskulinizacji sfery politycznej w Polsce jest wyjątkowo wysoki i niewielki udział kobiet w kształtowaniu opinii publicznej poprzez mass media oddaje tylko ogólniejszą, powszechniejszą tendencję.

Trzeci z kolei rozdział, którego autorką jest Agnieszka Łukasik-Turecka, nosi tytuł Obecność kobiet $w$ nieodpłatnych audycjach wyborczych radia publicznego na przykładzie wyborów do PE na Lubelszczyźnie w 2014 roku. Jest to materiał zbieżny $w$ dużym stopniu z poprzednim w sferze konkluzji, podejmujący zagadnienie stopnia reprezentatywności kobiet w szczególnym rodzaju aktywności politycznej, jakim jest partycypacja w procedurach wyborczych do Parlamentu Europejskiego w 2014 roku na Lubelszczyźnie. Tekst jest prezentacją analizy ilościowej składu i potencjału politycznego członkiń komitetów wyborczych delegujących kandydatów do Parlamentu Europejskiego. Wynik tych zestawień i prezentacji wskazuje na nierówny dostęp do możliwości promocji kobiet $w$ tych wyborach, pociągający za sobą obniżenie ich szans na pozytywny wynik wyborczy. Tekst wpisuje się w tematykę tomu i uzasadnia zarówno tytuł, jak sposób podejścia do ujęcia problemu.

Następny artykuł dotyczy udziału kobiet w polityce współczesnej Grecji. Akurat historia tego kraju pełna jest spektakularnej - poczynając od Lizystraty - obecności kobiet w życiu publicznym. Tekst pt. Kobiety w polityce współczesnej Grecji, którego autorką jest Iwona Jakimowicz-Pisarska, otwiera część tomu poświęconą miejscu i roli kobiet w polityce poza Polską. Kultura polityczna Grecji, stanowiąca jeden z filarów europejskiej, zachodniej cywilizacji i zasad demokracji, nie odbiega obecnie - jak dowodzi 
autorka - od wzorców patriarchalnego, zmaskulinizowanego modelu władzy politycznej. Niski poziom aktywności kobiet w sferze polityki w Grecji pogłębiony jest zdaniem badaczki przez kryzys społeczny i finansowy kraju. Tekst, podobnie jak poprzednie, wskazuje na asymetryczny, nierówny udział kobiet w polityce, nieprzekraczający podobnie jak w innych przypadkach progu 20-procentowego.

Identyczny niemal w konkluzjach i analizie przyczyn jest kolejny rozdział, autorstwa Ewy Bujwid-Kurek, zatytułowany Kobieta albańska w Kosowie - między prawem stanowionym a prawem zwyczajowym. Tekst ma charakter opisowo-analityczny: poświęcony został charakterystyce stanu prawnego i przeglądowi najważniejszych aktów normatywnych obowiązujących w Republice Kosowa, regulujących udział kobiet w życiu publicznym. Najważniejsze akty prawne obowiązujące w państwie oraz regulujące prawa i obowiązki obywatelskie spełniają standardy wynikające $z$ demokracji. Silne ciążenie tradycji prowadzi do nakładania się na siebie $w$ tym kraju dwóch porządków normatywnych: prawa zwyczajowego, określanego jako Kanun, i formalno-instytucjonalnego, konstytucyjnego. Niezależnie od istniejących reguł prawnych ciążenie zwyczaju, tradycji bywa przeszkodą w stosowaniu i praktykowaniu reguł prawnych. Tradycja podtrzymuje uprzywilejowaną rolę mężczyzn, akceptowaną powszechnie także przez kobiety. Religijne, islamskie podłoże tego stanu rzeczy prowadzi do konkluzji, że mała aktywność kobiet w polityce Kosowa posiada korzenie kulturowe. Zmiana politycznego statusu i położenia kobiet wydaje się zatem w Kosowie niemożliwa bez głębokiej reorientacji wartości i norm kulturowych, w tym religijnych i obyczajowych. Podobnie jak w przypadku omówionych już rozdziałów mam nieodparte wrażenie, że tekst podporządkowany jest, jak w celowym przedsięwzięciu, uzasadnieniu z góry przyjętej tezy o nierówności płciowej w polityce. Wrażenie to jednak posiada uzasadnione nie tyle perspektywą metodologiczną, ile faktycznym stanem rzeczy przyczyny. I jako męski recenzent nie potrafię się powstrzymać przed poczuciem winy.

Na podłoże kulturowe nierównej partycypacji kobiet w polityce, co jest już normą w tym tomie, wskazuje także Ewa Trojnar w artykule pt. Droga kobiet do polityki na Tajwanie w kontekście wyborów powszechnych w 2016 roku. Jest to interesujący tekst, opisujący i analizujący następstwa zderzenia dwóch systemów myślowych i modeli ideologicznych. Jeden z nich wyrasta na gruncie tradycyjnej, konfucjańskiej, konserwatywnej myśli politycznej, wykluczającej kobiety z udziału w polityce, drugi jest wnoszony przez 
prozachodnie, demokratyczne, liberalne elity, krytyczne wobec chińskiego dziedzictwa kulturowego. Autorka wyjaśnia warunki społeczne, w jakich nastąpiła modernistyczna reorientacja, prowadząca do otwarcia sfery publicznej dla kobiet. Nie zmienia to jednak ostatecznie faktu, że nawet w sytuacji, gdy urząd prezydenta w tym kraju sprawuje kobieta - reprezentantka starej elity rodowej, liczba kobiet na stanowiskach państwowych nie wzrasta. To dojrzały tekst, pasujący do tematyki tomu, wychodzący poza europejskie standardy prawne i kulturowe.

Wywód Joanny Wardęgi pt. W poszukiwaniu połowy nieba - kobiety w polityce Chin dotyczy tego samego obszaru cywilizacyjnego, co poprzedni. Autorki reprezentują podobną szkołę teoretyczną i metodologiczną, wywodzą się z tego samego ośrodka naukowego i należą do nowego, młodego pokolenia badaczy znających doskonale kraje, które opisują. Nawet dla zwykłego laika jest oczywiste, że rzeczywistość społeczna i kulturowa Chin wyrasta z bardzo bogatej, trwałej i silnej tradycji, której częścią jest także w dużej mierze kultura Tajwanu. Jest to kolejny krąg kulturowo-cywilizacyjny podporządkowany patriarchalnemu modelowi strukturalnemu, w którym kobiety mogą uczestniczyć w życiu politycznym w ograniczonym i ściśle reglamentowanym zakresie, zwykle w związku z przynależnością do określonych grup rodowych i kategorii społecznych.

Kolejny tekst poświęcony jest miejscu kobiet w politycznym systemie Stanów Zjednoczonych. Kraj ten był jednym z pionierskich w staraniach kobiet o równouprawnienie. Elżbieta Wiącek, autorka rozdziału zatytułowanego Amerykańskie sufrażystki i Irokezi, czyli historia o tym, jak kontakty międzykulturowe ze społecznościq indiańskq zainspirowały ruch o równouprawnienie kobiet w USA, włącza się w dominujący w tomie dyskurs, śledząc proces kobiecego buntu wobec podstaw amerykańskiej i chrześcijańskiej zarazem odmiany patriarchalizmu. Wiącek uwzględnia w swojej analizie mało znane w Polsce, mocno eksponowane w Ameryce elementy obywatelskiego nieposłuszeństwa, wyrastające na gruncie kontestacji etnicznej i kobiecej. To wartościowy tekst, rozszerzający zakres problemowy i terytorialny wywodu, należący do krytyczno-konstruktywnej metodologii i podłoża teoretycznego wspólnego dla wszystkich autorek tomu.

Nie dziwi zatem, że kolejny, przedostatni tekst, dotyczący położenia i roli kobiet $w$ sferze publicznej $w$ Turcji, prowadzi do podobnych wniosków i uogólnień. Jego autorka, Filiz Sulejman-Srokosz, podejmuje ten wątek $w$ rozdziale zatytułowanym Tureckie pracownice seksualne $w$ drodze do parlamentu. Znająca dobrze język i kulturę Turcji autorka ukazuje, 
podobnie jak wcześniej miało to miejsce w odniesieniu do Tajwanu, Grecji, Polski i innych krajów, sprzeczności i bariery kulturowe i prawne wynikające we współczesnej Turcji ze zderzenia dwóch systemów ideologicznych: tradycyjnego, religijnego, islamskiego, i nowoczesnego, świeckiego, wywodzącego się z kulturowych i cywilizacyjnych zmian wprowadzonych przez Kemala Atatürka na początku XX wieku. Autorka opisuje ów proces, prowadzący do częściowej emancypacji kobiet, nie pomijając także negatywnych przejawów i następstw zderzenia kulturowego.

Ostatni tekst, Ellen Key i szwedzki "dom ludu” (folkhemmet), autorstwa redaktorki całego tomu, wnosi wiele optymizmu i nadziei na pozytywne przemiany, prowadzące do realnego, a nie jedynie deklarowanego równouprawnienia kobiet w każdej sferze życia publicznego, nie tylko w polityce. Monika Banaś przywołuje przeciwną do większości opisanych tradycję społeczną, w której inny model roli kobiet w życiu publicznym i koncepcję ich równouprawnienia kreśli Ellen Key, szwedzka działaczka społeczna przełomu wieków XIX i XX. Koncepcja ta stała się podstawą nowego porządku społecznego, a także politycznego, zwanego folkhemmet (szw. "dom ludu”). Udany, funkcjonujący w krajach nordyckich model politycznej partycypacji w socjaldemokratycznym ustroju politycznym prowadzi do rzeczywistego, a nie tylko normatywnego równoprawnego udziału kobiet i mężczyzn w systemie politycznym. Artykuł zamykający tom przedstawia pozytywną wizję systemu społecznego i politycznego, w którym kobiety na równi z mężczyznami uczestniczą w życiu politycznym. Tekst reprezentuje, tak jak pozostałe, wysoki poziom merytoryczny i udanie wpisuje się $w$ tematykę i problematykę tomu.

Publikację zamyka bibliografia oraz indeks nazwisk. Monografia stanowi kompletną, spełniającą rygory metodologiczne i warsztatowe, jednorodną tematycznie całość. Problematyka tomu, sposób jej prezentacji, widoczny w całej monografii zamysł opisowo-diagnostyczny i teoretyczny uzasadniają merytoryczną wartość i wagę pozycji. Nie sposób zarazem pozbyć się wrażenia niedosytu. Tom mógłby być obszerniejszy, objąć większą liczbę krajów, systemów politycznych, kultur i cywilizacji. Nie zmienia to jednak faktu, że udziałowi kobiet w polityce należy poświęcić więcej miejsca, uwagi - i że recenzowana monografia jest dobrym punktem wyjścia do kontynuowania tego dyskursu, może jednak - na wzór szwedzki - także z udziałem mężczyzn. Publikacja zapełnia lukę na rynku wydawniczym i powinna zostać dostrzeżona i wzbudzić reakcję szerszego grona odbiorców. Także spoza środowiska akademickiego. 